\title{
Technological prospection of anti-inflammatory vanilic acid activity, with emphasis on its semisynthetic derivative Isopropyl Vanilate
}

\author{
Prospecção tecnológica da atividade anti-inflamatória do Acído Vanílico, com ênfase em seu \\ derivado semissintético Vanilato de Isopropila \\ Prospección tecnológica de la actividad del Ácido Vanílico antlinflamatorio, con énfasis en su \\ derivado semisintético de vanilato de isopropilo
}

Received: 03/01/2021 | Reviewed: 03/06/2021 | Accept: 03/11/2021 | Published: 03/18/2021

\author{
Kerolayne de Melo Nogueira \\ ORCID: https://orcid.org/0000-0003-0112-0760 \\ Federal University of Ceará, Brazil \\ E-mail: kerolayne.nogueira@santaines.itpac.br \\ Luan Kelves Miranda de Souza \\ ORCID: https://orcid.org/0000-0002-8019-4022 \\ Faculty of Human, Exact and Health Sciences of Piauí, Brazil \\ E-mail: luan.souza@iesvap.edu.br \\ Jand Venes Rolim Medeiros \\ ORCID: https://orcid.org/00000002 72343382 \\ Federal University of Parnaíba Delta, Brazil \\ E-mail: jandvenes@ufpi.edu.br
}

\begin{abstract}
Inflammation is the body's response to harmful stimuli such as infections, trauma, or injury. The inflammatory cascade can lead to the development of numerous diseases, and the current drug-therapeutic intervention consists of the use of corticosteroids and non-steroidal anti-inflammatory drugs. However, the use of these is associated with several serious side effects, so it is necessary to search for new alternatives that can minimize this effect. In this prospecting, the objective was to conduct a study on biological activities already described for vanillic acid, with special emphasis on its semi-synthetic derivative of isopropyl vanylate as an anti-inflammatory agent. For this, information was obtained on patent documents based on the INPI, USPTO and EPO databases, using the keywords: vanillic acid, anti-inflammatory agents, isopropyl vanylate, always used in the search field related to the summary of works. As results obtained in the present technological prospection study, it was found that in the international patent databases the documents related to the theme were very scarce and some had a higher number of patents, on vanillic acid, few refer to its anti-inflammatory, and no documents were found on the use of isopropyl vanillate as an anti-inflammatory agent, reinforcing the innovative character of research involving its use in this technology.
\end{abstract}

Keywords: Vanillic acid; Isopropyl vanylate; Inflammation.

\section{Resumo}

Inflamação é a resposta do corpo à estímulos nocivos tais como: infecções, traumas ou lesões. A cascata inflamatória pode levar ao desenvolvimento de inúmeras doenças, e a intervenção farmacoterapêutica atual consiste no uso de corticosteroides e de anti-inflamatórios não-esteroides. Entretanto, a utilização destes está associada a vários efeitos secundários graves, por isso é necessária a busca por novas alternativas que possam minimizar esse efeito. Nesta prospecção, objetivou-se realizar um estudo sobre atividades biológicas já descritas para o ácido vanílico, com especial destaque para o seu derivado semissintético vanilato de isopropila enquanto agente anti-inflamatório. Para isso, foram obtidas informações sobre documentos de patentes nas bases INPI, USPTO e EPO, com o uso das palavras-chave: ácido vanílico, agentes anti-inflamatórios, vanilato de isopropila, sempre utilizados no campo de busca relativo ao resumo dos trabalhos. Como resultados obtidos no presente estudo prospecção tecnológica verificou-se que nas bases de dados internacionais de patente os documentos referentes à temática eram muito escassos e algumas tinham um maior número de patentes, sobre o ácido vanílico, poucas referem-se a sua atividade anti-inflamatória, e não foram encontrados documentos sobre a utilização do vanilato de isopropila como agente anti-inflamatório, reforçando o caráter inovador das pesquisas que envolvem o seu uso nesta tecnologia.

Palavras-chave: Ácido vanilico; Vanilato de isopropila; Inflamação.

\section{Resumen}

La inflamación es la respuesta del cuerpo a estímulos dañinos como infecciones, traumatismos o lesiones. La cascada inflamatoria puede conducir al desarrollo de numerosas enfermedades, y la intervención farmacoterapéutica actual 
consiste en el uso de corticosteroides y antiinflamatorios no esteroideos. Sin embargo, el uso de estos se asocia a varios efectos secundarios graves, por lo que es necesario buscar nuevas alternativas que puedan minimizar este efecto. En esta prospección, el objetivo fue realizar un estudio sobre las actividades biológicas ya descritas para el ácido vainílico, con especial énfasis en su derivado semisintético de vanilato de isopropilo como agente antiinflamatorio. Para ello, se obtuvo información sobre documentos de patente basados en las bases de datos del INPI, USPTO y EPO, utilizando las palabras clave: ácido vainílico, agentes antiinflamatorios, vanilato de isopropilo, siempre utilizados en el campo de búsqueda relacionado con el resumen de trabajos. Como resultados obtenidos en el presente estudio de prospección tecnológica, se encontró que en las bases de datos internacionales de patentes los documentos relacionados con el tema eran muy escasos y algunos tenían un mayor número de patentes, sobre el ácido vainílico, pocos se refieren a su antiinflamatorio, y no se encontraron documentos sobre el uso de isopropil vainilla como agente antiinflamatorio, lo que refuerza el carácter innovador de las investigaciones que involucran su uso en esta tecnología.

Palabras clave: Ácido vainílico; Vanilato de isopropilo; Inflamación.

\section{Introduction}

Inflammation is the body's response to tissue damage and occurs as a defensive response, which induces profound physiological adaptations triggered in an attempt to limit tissue damage and remove the pathogen. Such mechanisms involve a complex series of events, including the dilation of arterioles, venules and capillaries with increased vascular permeability, fluid exudation, including plasma proteins and leukocyte migration to the inflammatory site. Such an inflammatory response can be triggered by several stimuli, such as: endogenous origin (necrosis tissues, tumor staging), exogenous originating from infections caused by microorganisms, trauma (blunt or penetrating), physical agents (burns or freezing) and chemicals such as radiation and environmental chemicals (Gabay; Kushner, 1999; Lalrinzuali; Vabeiryureilai; Jagetia, 2016; Hu; Shu, 2021).

Although inflammation is a defense mechanism, it is the chronification of this process that leads to deleterious effects on the body, mainly due to the action of mediators involved in this reaction, thus being able to perpetuate and aggravate many diseases (Headland; Norling, 2015; Kumar; Chan; Coussens, 2016; Hou, Michael, Beicheng, 2021). In this context, diseases characterized by the chronicity of the inflammatory process are directly related to the increase in cases of morbidity and mortality, especially in elderly individuals. The inflammatory cascade can lead to the development of diseases such as: rheumatoid arthritis, atherosclerosis, alzheimer, neoplasia, asthma, psoriasis, multiple sclerosis, gastroenteritis, autoimmune diseases and diabetes (Perkins et al., 2015; Who, 2017).

Regardless of the inflammatory process is indispensable for the individual's homeostasis, the deleterious effects caused by this response require, in certain cases, pharmacotherapeutic intervention. The drugs generally prescribed and which are able to interfere in this reaction process of the body are: glucocorticoids or steroidal anti- inflammatory drugs (AIEs) and non-steroidal anti-inflammatory drugs (NSAIDs) (Figure 5). AINes act by interfering with the synthesis of prostaglandins through unspecific inhibition of the synthesis of COX-1 and / or COX-2. However, the use of these is associated with several serious side effects. Although effective, the continuous use of NSAIDs is associated with a set of side effects, mainly gastrointestinal toxicity (Horadagoda et al., 1999; Perkins et al, 2015; El-dash et al., 2021).

Gastric injury caused by NSAIDs has generally been associated with non-specific inhibition of cyclooxygenase (COX) isoforms, thereby blocking the production of endogenous substances responsible for gastric reepithelialization, such as the inhibition of prostaglandins (PGs), in particular the PGE2 (Kawahara et al., Gunter, 2017; El-dash et al., 2021).

Therefore, the search for therapeutic alternatives that have good anti-inflammatory activity without causing the deleterious effects of current drugs is extremely important. In this sense, natural products are an important source for research aimed at the discovery of new substances with pharmacological activities for the possible development of drugs. In recent years, these natural compounds have guided the development of organic chemistry leading to advances in synthetic methodologies, enabling the synthesis of compounds with chemical structures similar to natural products. At the end of the process, these semisynthetic compounds can be patented, even when their original structure has been previously described (Newman, 2008; Cragg; 
Newman 2013; David; Wolfender, 2015; Newman et al., 2016; Atanasov et al., 2021).

Gastric injury caused by NSAIDs has generally been associated with non-specific inhibition of cyclooxygenase (COX) isoforms, thereby blocking the production of endogenous substances responsible for gastric reepithelialization, such as the inhibition of prostaglandins (PGs), in particular the PGE2 (Kawahara et al., Gunter, 2017).

Therefore, the search for therapeutic alternatives that have good anti-inflammatory activity without causing the deleterious effects of current drugs is extremely important. In this sense, natural products are an important source for rese arch aimed at the discovery of new substances with pharmacological activities for the possible development of drugs. In recent years, these natural compounds have guided the development of organic chemistry leading to advances in synthetic methodologies, enabling the synthesis of compounds with chemical structures similar to natural products. At the end of the process, these semisynthetic compounds can be patented, even when their original structure has been previously described (Newman, 2008; Cragg; Newman 2013; David; Wolfender, 2015; Newman et al., 2016).

Among the natural products, phenolic compounds have been decreasing in scientific research, as they have demonstrated plurifarmacological effects such as: bactericidal, antiviral, antiallergic, antithrombotic, anticarcinogenic, hepatoprotective, vasodilator and anti-inflammatory (Butler; Robertson; Cooper, 2014; Koeberle; Oliver, 2014; Newman et al., 2016; Rodrigues et al., 2016; Campos, 2015; Atanasov et al., 2021).

In the context of these phenolic compounds, vanillic acid has been highlighted, where experimental studies have provided evidence of its efficacy in cardiovascular, gastrointestinal and liver diseases. In addition, it has anti-inflammatory activity by inhibiting the synthesis of numerous mediators that rise during inflammatory processes in addition to acting directly on lipid peroxidation (Sevgi, Tepe, Sarikurkcu, 2015; Calixto-campos et al., 2015; Dianat et al., 2016; Vinothiya and Ashokkumar, 2017; Nogueira et al., 2019).

In this prospecting, the objective was to conduct a study on biological activities already described for vanillic acid, with special emphasis on its semi-synthetic derivative of isopropyl vanylate as an anti-inflammatory agent. For this, information was obtained on patent documents based on the INPI, USPTO and EPO databases, using the keywords: vanillic acid, antiinflammatory agents, isopropyl vanylate, always used in the search field related to the summary of works.

\section{Methodology}

This research was carried out based on a survey of patent applications filed in the main databases: United States Patent and Trademark Office (USPTO), European Patent Office (EPO), World Intellectual Property Organization (WIPO) and the Bank's database. National Institute of Industrial Property (INPI) of Brazil. The survey was carried out in February 2021, investigating all patent documents available for consultation until the date of the survey (25/02/2021). The searches were carried out using as keywords the terms "vanillic acid", "Anti-inflammatory agents" combined or not and "Isopropyl vanillate", in Portuguese and English together with the Boolean operator "and" in all bases, eventually associating the terms with the use of quotation marks (““). In view of the need to carry out a broader search, such keywords and Boolean operator were always used in the search field related to the summary. The technical procedures applicable to all data collection refer to the search for patent deposits and official collections and databases that provide information on the parameters analyzed in that research were carried out according to the relevant methodology for this type of research (Pereira et al.,2018).

\section{Results and Discussion}

The results obtained in the present technological prospecting study refer to all patent deposits made and published on the subject in question recovered through the search used (Figure 1), considering, as regards patent deposits, the country and the 
year of filing, as well as the International Patent Classification (CIP).

Regarding the international classification, approximately $45.03 \%$ of the patents were deposited in the A61 code area of preparation for medical purposes and preparations of compounds with specific activities or medicinal preparations and 54.97\% of the patents were deposited in the area of agriculture with codes $\mathrm{C} 7, \mathrm{C} 8, \mathrm{C} 12$ covering agriculture and specific chemical formulations.

The results of the technological prospecting presented refer, as already mentioned, to the patent documents already filed involving the subject under analysis, in the databases of EPO, INPI, USPTO and WIPO respectively. In the national patent base of the INPI (Figure 1), only 3 patents were found in relation to the keyword vanillic acid involving biocide composition deposited in 2016, the manufacture of an oxidized reaction product deposited in 2015 and the manufacture of a co-crystal and its use to treat thrombotic complications filed in 2012 but no patent related to the biological activity of vanillic acid, on the other hand the search for the term isopropyl vanylate did not return results.

Figure 1. Results obtained for the search for the term 'Vanillic acid' 'Anti-Inflammatory Agent' and 'Vanillic acid and inflammation' across the three patent bases USPTO, EPO, INPI and WIPO regarding the number of filings for patent applications.

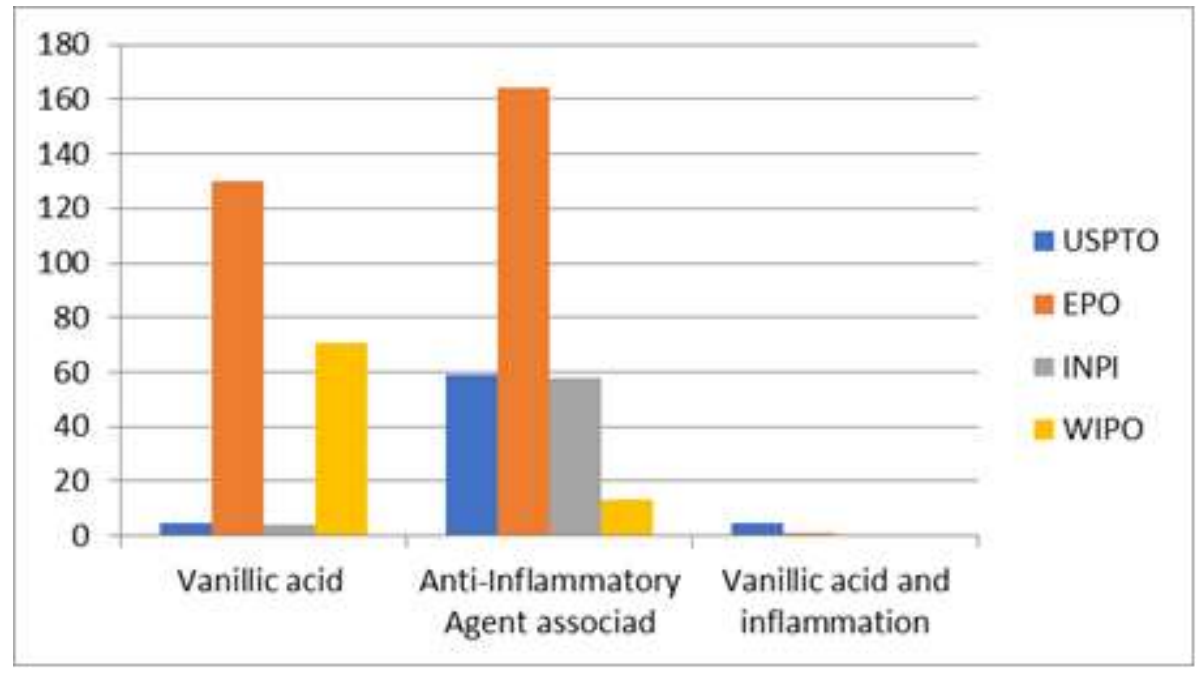

Source: Prepared by the authors from USPTO, EPO, INPI, WIPO (2021).

It can be observed that when the search for the associated terms was carried out, very poor results were returned showing the potential of the development and the filing of patents related to isopropyl vanylate and its anti-inflammatory activity. The search for a patent at the INPI with the descriptor 'Anti-inflammatory agent' returned 23 results that can be seen in Figure 2, which in summary describe, pharmaceutical compositions of drug combinations and some new anti-inflammatory drugs from natural derivatives such as polysarides, methods alternatives for treating inflammation. On the other hand, the search for the descriptor 'isopropyl vanylate' did not return any results. 
Figure 2. Results obtained for the search for the term 'Anti-Inflammatory Agent' in the INPI patent base for the years of filing of patent applications.

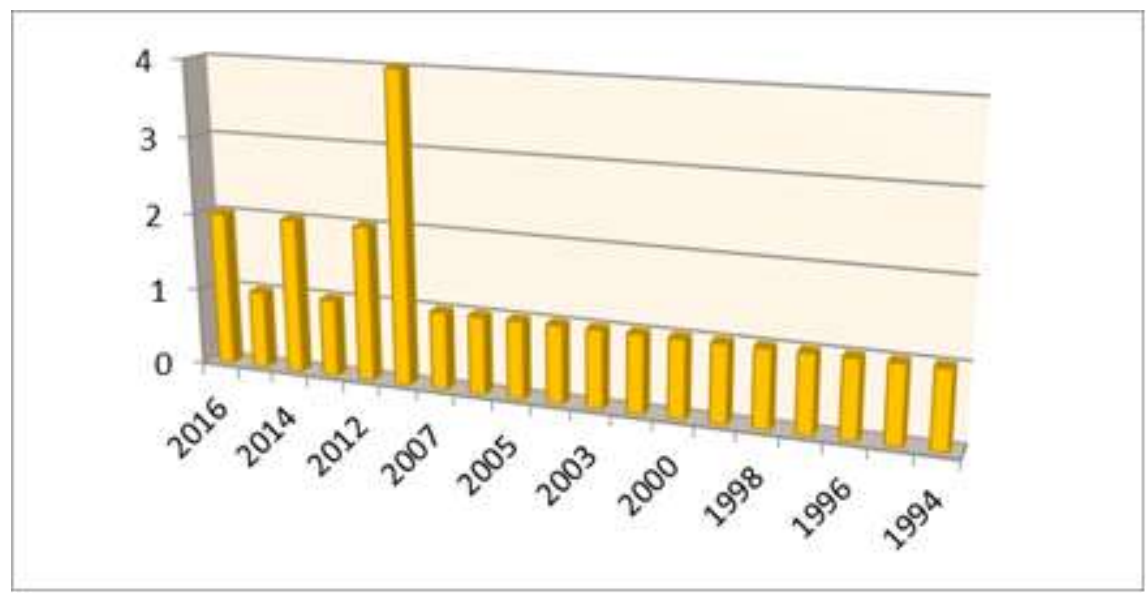

Source: Prepared by the authors from INPI (2021).

The American patent base of the USPTO returned 5 results for patents related to the keyword vanillic acid (Figure 3), and are related to the synthesis process, or methods of preparation and production of vanillic acid, only 3 mention the biological activity of the acid vanillic, as a bactericide, antifungal used in the production of co-crystals for platelet inhibition and a patent for combining molecules to treat cancer, but the search for the term isopropyl vanylate did not return results.

Figure 3. Results obtained for the search for the term 'vanillic acid' on the basis of USPTO and INPI patents regarding the years of filing of patent applications.

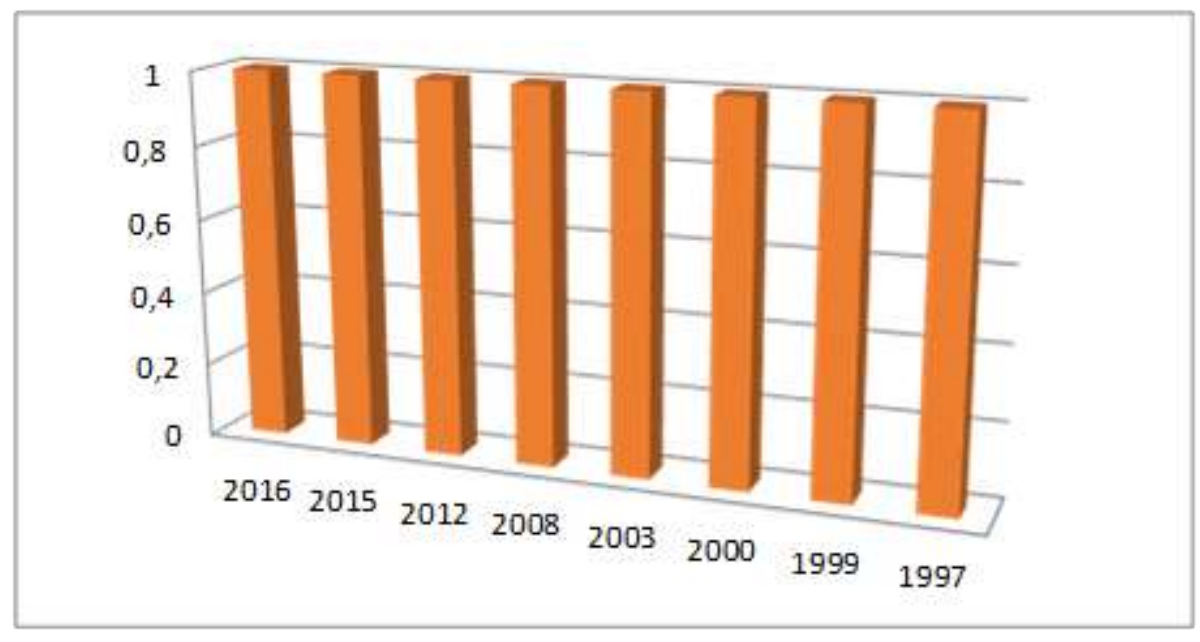

Source: Prepared by the authors from USPO and INPI (2021).

In the EPO database, 130 patents were found for the keyword vanillic acid as shown in Figure 4, of which only 5 related to its use in inflammation, which describe the use in the treatment of allergic diseases, in the production of capsules to treat urethritis, production of new chemotherapeutic agents for the treatment of cancer, analysis of the analgesic effect of a Chinese plant in which vanillic acid is one of the constituents and production of TNf- $\alpha$ inhibitors. However, for the most part the search corresponds to methods of production, extraction and preparation of extracts containing vanillic acid, as well as in the other database there are some patents for bacterial and antifungal activity. However, when searching for patents using the terms isopropyl vanylate, the search did not return any results. 
Figure 4. Results obtained for the search for the term 'vanillic acid' on the basis of EPO patents regarding the years of filing of patent applications.

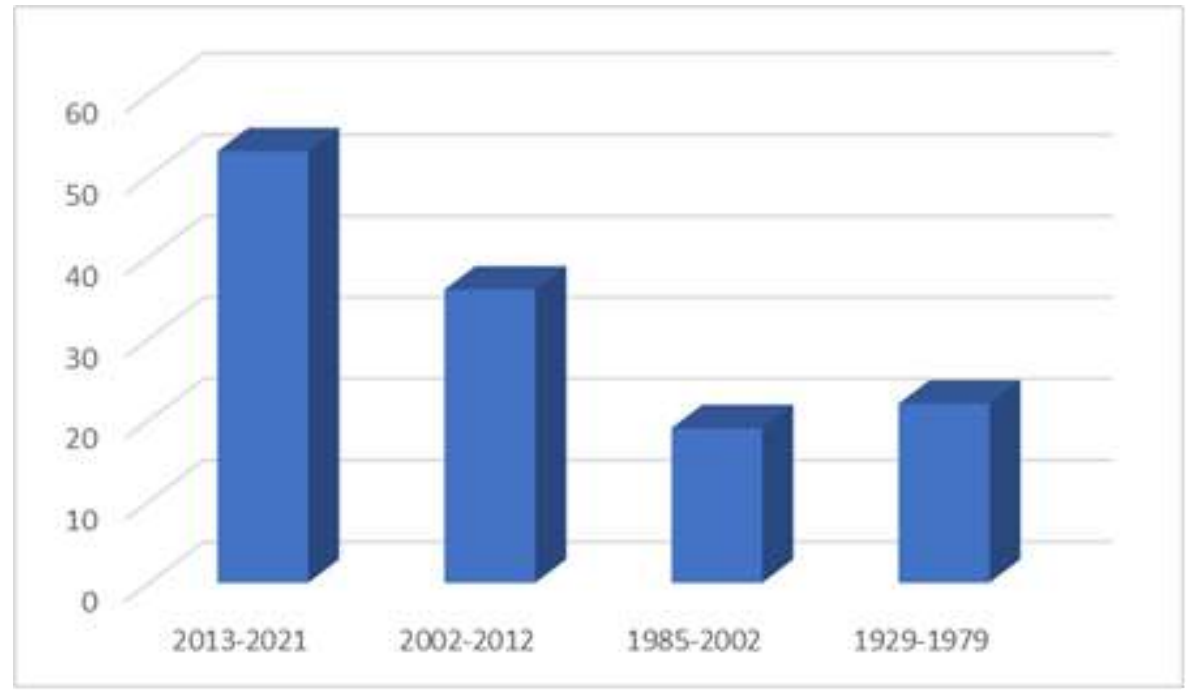

Source: Prepared by the authors from EPO (2021).

The search for the keyword 'Anti-inflammatory agent' in the USPTO database returned 170 results (Figure 5). Most of the results are related to the protection of formulations related to the development of non-steroidal anti-inflammatory drugs, as well as new formulations of some that already exist on the market, other patents describe the associated use of anti-inflammatory drugs to treat other diseases, or patents for the production of new drugs, or drugs derived from natural products such as quercetin, which is also a phenolic compound derived as well as vanillic acid. However, no results were returned on this basis after searching for the 'Isopropyl vanillate ad inflammation' association.

Figure 5. Results obtained for the search for the term 'Anti-Inflammatory Agent' in the USPTO patent base regarding the years of filing of patent applications.

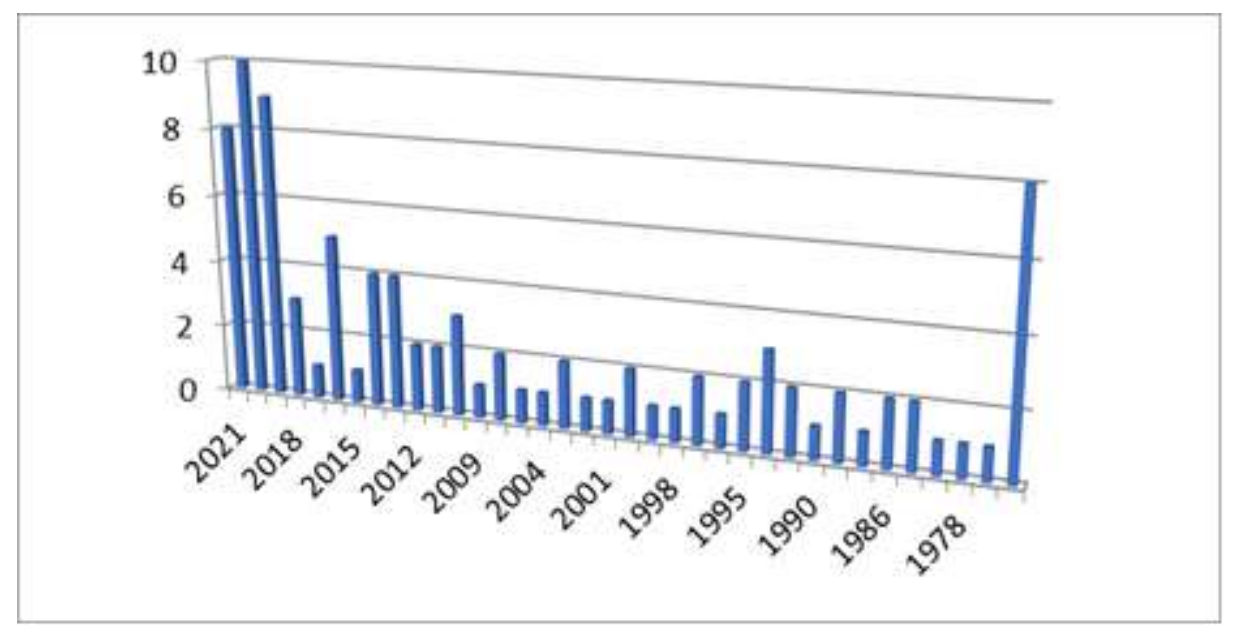

Source: Prepared by the authors from USPTO (2021).

The search for the keyword 'AntiInflammatory agent' in EPO returned 164 results (Figure 6). Most of the results are related to the protection of formulations related to the development of non-steroidal anti-inflammatory drugs, as well as new formulations of some that already exist on the market, other patents describe the associated use of anti-inflammatory drugs to treat other diseases, or patents for the production of new drugs, or drugs derived from natural products such as quercetin, which 
is also a phenolic compound derived as well as vanillic acid. However, no results were returned on this basis after searching for the association 'Isopropyl vanillate and inflammation'.

In Figure 7, it can be seen that companies hold the largest number of patent deposits, with individual inventors in second place and universities in last, showing that this area is quite the target of industries and quite profitable from a commercial point of view. Evidencing the potential of this area for technological development.

Figure 6. Results obtained for the search for the term 'Anti-Inflammatory Agent' on the basis of EPO patents regarding the years of filing of patent applications.

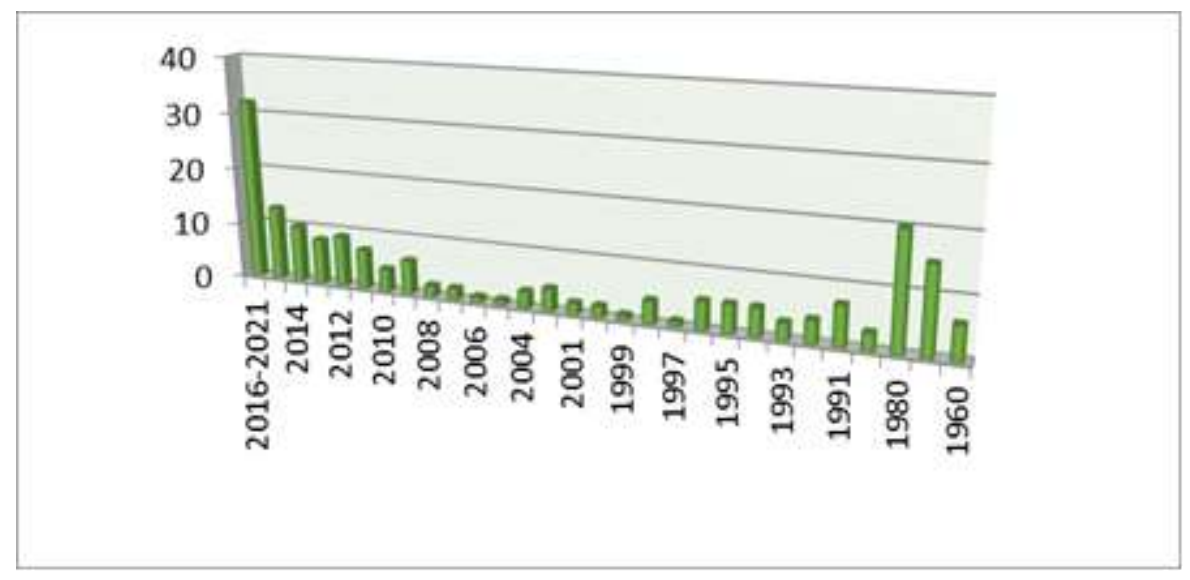

Source: Prepared by the authors from EPO (2021).

Figure 7. Distribution of related patent documents by type of depositor.

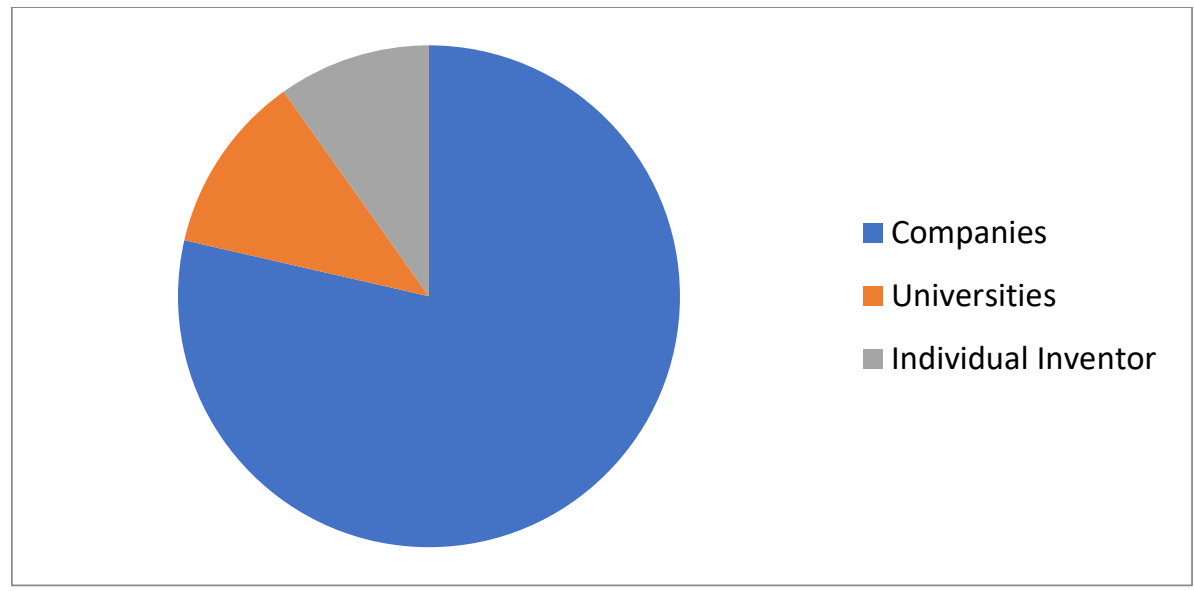

Source: Prepared by the authors from EPO, WIPO, INPI, USPTO (2021).

\section{Conclusion}

Results exposed in this work point out that, although the number of patents filed involving are a relatively small number, with a few hundred deposits, little has been applied in the development of new anti-inflammatory drugs, since the number of patent filing requests involving its association with the treatment of inflammation is scarce, and non-existent in the search for patents involving its semi-synthetic derivative, isopropyl vanylate, which has only one published article demonstrating the Efficacy of a phenol derivative, isopropyl vanillate, as an anti-inflammatory agent: A new small molecule inhibitor of COX and neutrophil migration (Nogueira et al., 2019), thus highlighting the potential of this substance and the importance of its patent. 
This study may suggest the application and use of Isopropyl Vanylate in several thematic areas, especially in the treatment of inflammation where until now there is only one article proving its effect and effectiveness, such a molecule can represent a good pharmacological target for the treatment of these diseases, since it is a small and easily obtained molecule (apart from vanillic acid).

\section{References}

Atanasov, A. G., Zotchev, S. B., Dirsch, V. M., \& Supuran, C. T. (2021). Natural products in drug discovery: advances and opportunities. Nature Reviews Drug Discovery, 1-17.

Butler, M. S., Robertson, A. A., \& Cooper, M. A. (2014). Natural product and natural product derived drugs in clinical trials. Natural product reports, 31(11), $1612-1661$.

Calixto-Campos, C., Carvalho, T. T., Hohmann, M. S., Pinho-Ribeiro, F. A., Fattori, V., Manchope, M. F., ... \& Verri Jr, W. A. (2015). Vanillic acid inhibits inflammatory pain by inhibiting neutrophil recruitment, oxidative stress, cytokine production, and NFKB activation in mice. Journal of natural products, 78(8), 1799-1808.

Choi, E., Roland, J. T., Barlow, B. J., O'Neal, R., Rich, A. E., Nam, K. T., \& Goldenring, J. R. (2014). Cell lineage distribution atlas of the human stomach reveals heterogeneous gland populations in the gastric antrum. Gut, 63(11), 1711-1720.

Choi, Y. J., Kim, N., Lee, J. Y., Nam, R. H., Seo, J. H., Lee, S., \& Lee, D. H. (2016). Gastroprotective effects of PMK-S005 against ethanol-induced acute gastric damage in rats. Gut and liver, 10(3), 348.

Cragg, G. M., \& Newman, D. J. (2013). Natural products: a continuing source of novel drug leads. Biochimica et Biophysica Acta (BBA)-General Subjects, 1830(6), 3670-3695.

David, B., Wolfender, J. L., \& Dias, D. A. (2015). The pharmaceutical industry and natural products: historical status and new trends. Phytochemistry Reviews, 14(2), 299-315.

Dianat, M., Radmanesh, E., Badavi, M., Mard, S. A., \& Goudarzi, G. (2016). Disturbance effects of PM 10 on iNOS and eNOS mRNA expression levels and antioxidant activity induced by ischemia-reperfusion injury in isolated rat heart: protective role of vanillic acid. Environmental Science and Pollution Research, 23(6), 5154-5165.

El-Dash, Y., Khalil, N. A., Ahmed, E. M., \& Hassan, M. S. (2021). Synthesis and biological evaluation of new nicotinate derivatives as potential antiinflammatory agents targeting COX-2 enzyme. Bioorganic Chemistry, 107, 104610.

Gabay, C., \& Kushner, I. (1999). Acute-phase proteins and other systemic responses to inflammation. New England journal of medicine, 340(6), $448-454$.

Gunter, B. R., Butler, K. A., Wallace, R. L., Smith, S. M., \& Harirforoosh, S. (2017). Non-steroidal anti-inflammatory drug-induced cardiovascular adverse events: a meta-analysis. Journal of clinical pharmacy and therapeutics, 42(1), 27-38.

Headland, S. E., \& Norling, L. V. (2015). The resolution of inflammation: Principles and challenges. In Seminars in immunology (Vol. 27, No. 3, pp. 149-160). Academic Press.

Horadagoda, N. U., Knox, K. M. G., Gibbs, H. A., Reid, S. W. J., Horadagoda, A., Edwards, S. E. R., \& Eckersall, P. D. (1999). Acute phase proteins in cattle: discrimination between acute and chronic inflammation. Veterinary Record, 144(16), 437-441.

Hou, J., Michael K., Beicheng S. (2021). "Targeting cancer-promoting inflammation—have anti-inflammatory therapies come of age?" Nature Reviews Clinical Oncology, 1-19.

Hu, M. M., \& Shu, H. B. (2020). Innate immune response to cytoplasmic DNA: mechanisms and diseases. Annual review of immunology, 38, 79-98.

Kawahara, K., Hohjoh, H., Inazumi, T., Tsuchiya, S., \& Sugimoto, Y. (2015). Prostaglandin E2-induced inflammation: Relevance of prostaglandin E receptors. Biochimica et Biophysica Acta (BBA)-Molecular and Cell Biology of Lipids, 1851(4), 414-421.

Killeen, M. J., Linder, M., Pontoniere, P., \& Crea, R. (2014). NF- $\kappa \beta$ signaling and chronic inflammatory diseases: exploring the potential of natural products to drive new therapeutic opportunities. Drug discovery today, 19(4), 373-378.

Koeberle, A., \& Werz, O. (2014). Multi-target approach for natural products in inflammation. Drug Discovery Today, 19(12), 1871-1882.

Kumar, S., Chan, C. J., \& Coussens, L. (2016). Inflammation and cancer. In Immunity to Pathogens and Tumors (pp. 406-415). Elsevier Inc.

Lalrinzuali, K., Vabeiryureilai, M., \& Jagetia, G. C. (2016). Investigation of the anti-inflammatory and analgesic activities of ethanol extract of stem bark of Sonapatha Oroxylum indicum in vivo. International journal of inflammation, 2016.

Newman, D. J. (2008). Natural products as leads to potential drugs: an old process or the new hope for drug discovery? Journal of medicinal chemistry, 51(9), 2589-2599.

Newman, D. J., \& Cragg, G. M. (2016). Natural products as sources of new drugs from 1981 to 2014. Journal of natural products, 79(3), 629-661.

Nogueira, K. M., de Souza, L. K., de Oliveira, A. P., Pacheco, G., Iles, B., Alencar, M. S., \& Medeiros, J. V. (2019). Efficacy of a phenol derivative, isopropyl vanillate, as an anti-inflammatory agent: A new small molecule inhibitor of COX and neutrophil migration. Drug development research, 80(5), 666-679. 
Research, Society and Development, v. 10, n. 3, e35910313451, 2021

(CC BY 4.0) | ISSN 2525-3409 | DOI: http://dx.doi.org/10.33448/rsd-v10i3.13451

Pereira, A. S., Shitsuka, D. M., Parreira, F. J., \& Shitsuka, R. (2018). Metodologia da Pesquisa Científica. UFSM. https://repositorio.ufsm.br/bitstream/handle/1/15824/Lic_Computacao_Metodologia-Pesquisa -Cientifica.pdf?sequence=1.

Perkins, J. R., Sanak, M., Canto, G., Blanca, M., \& Cornejo-García, J. A. (2015). Unravelling adverse reactions to NSAIDs using systems biology. Trends in pharmacological sciences, 36(3), 172-180.

Rodrigues, T., Reker, D., Schneider, P., \& Schneider, G. (2016). Counting on natural products for drug design. Nature chemistry, 8(6), 531.

Schubert, M. L. (2015). Functional anatomy and physiology of gastric secretion. Current opinion in gastroenterology, 31(6), 479-485.

Sevgi, K., Tepe, B., \& Sarikurkcu, C. (2015). Antioxidant and DNA damage protection potentials of selected phenolic acids. Food and Chemical Toxicology, 77, $12-21$.

Tili, E., \& Michaille, J. J. (2016). Promiscuous effects of some phenolic natural products on inflammation at least in part arise from their ability to modulate the expression of global regulators, namely microRNAs. Molecules, 21(9), 1263.

Tripathi, S., Flobak, Å., Chawla, K., Baudot, A., Bruland, T., Thommesen, L., ... \& Lægreid, A. (2015). The gastrin and cholecystokinin receptors mediated signaling network: a scaffold for data analysis and new hypotheses on regulatory mechanisms. BMC systems biology, 9(1), 1-15.

Vinothiya, K., \& Ashokkumar, N. (2017). Modulatory effect of vanillic acid on antioxidant status in high fat diet-induced changes in diabetic hypertensive rats. Biomedicine \& Pharmacotherapy, 87, 640-652.

Waldum, H. L., Kleveland, P. M., \& Fossmark, R. (2015). Upper gastrointestinal physiology and diseases. Scandinavian journal of gastroenterology, 50(6), 649-656.

Willet, S. G., \& Mills, J. C. (2016). Stomach organ and cell lineage differentiation: from embryogenesis to adult homeostasis. Cellular and molecular gastroenterology and hepatology, 2(5), 546-559.

Wolfender, J. L., Marti, G., Thomas, A., \& Bertrand, S. (2015). Current approaches and challenges for the metabolite profiling of complex natural extracts. Journal of Chromatography A, 1382, 136-164. 